\title{
Restorative Justice in Children's Criminal Jurisdiction System through Diversion
}

\section{Nur Indah Setyoningrum*) and Anis Mashdurohatun**)}

*) Student of Master of Law Program, Faculty of Law, Universitas Islam Sultan Agung email indahsetyoningrum890@gmail.com

${ }^{* *}$ ) Faculty of Law Universitas Islam Sultan Agung

\begin{abstract}
.
Diversion is a constructive effort to rebuild social relations that have been damaged by criminal acts, basically diversion has relevance to the purpose of punishment for children. The formulation of the problem is 1) How is the implementation of restorative justice in the Juvenile Criminal Justice System through diversion at the Semarang City District Attorney, 2) What are the obstacles in the implementation of restorative justice in the Juvenile Criminal Justice System through diversion at the Semarang City District Attorney. The method used is juridical empirical. The results of this study are: 1) This is due to the need for time to adjust to the new regulations in effect, in order to meet the completeness of supporting infrastructure and equitable distribution of trained and reliable human resources in every judicial institution in various regions throughout Indonesia, especially those dealing with child crimes. 2) The child protection system is not working in every case of children who are in conflict with the law
\end{abstract}

Keywords: Restorative Justice; Child Criminal Justice System; Diversion.

\section{Introduction}

The commitment of the state to guarantee child protection efforts is formulated in the 1945 Constitution of the Republic of Indonesia (UUDNRI 1945) Article 28B paragraph (2) which explains that every child has the right to live, grow and develop and has the right to protection from violence and discrimination. The 1945 Constitution Article 28B Paragraph (2) means that a child is included in the subject and color of the state and has the right to protection of constitutional rights from attacks by others. ${ }^{1}$ However, in reality there are still many human rights violations in the field of child protection. There are many kinds of human rights violations in the field of child protection. Among them are early marriage, lack of education, child trafficking, abuse and employment of minors. ${ }^{2}$

Children's rights are part of human rights guaranteed and protected by international law and national law, which are universally regulated, namely in the

\footnotetext{
${ }^{1}$ Gunarsa, Singgih D (Peny). (2004). Dari Anak Sampai Lanjut Usia. Jakarta: PT BPK Gunung Mulia. P. 120 .

2 Reksodiputro, Mardjono. (1997). Hak Asasi Manusia dalam Sistem Peradilan Pidana. Jakarta: Pusat Pelayanan Keadilan dan Pengabdian Hukum Lembaga Kriminologi Universitas Indonesia. p. 84.
} 
Universal Declaration of Human Rights (UDHR) and the International Covenant on Civil and Political Rights (ICCPR). ${ }^{3}$

To provide security to every citizen, it is necessary to take action by law enforcement officials to carry out legal proceedings against any person who commits an offense or criminal act. The implementation of law enforcement against criminals must be in a system consisting of subsystems that relate to one another called the criminal justice system or in English it is called the Criminal Justice System. ${ }^{4}$

The tendency of increasing violations committed by children or young perpetrators that lead to criminal acts, encourages efforts to handle and handle it specifically in the field of criminal law (children) and its programs. ${ }^{5}$ This is closely related to the special treatment of juvenile offenders. ${ }^{6}$ In the settlement of criminal acts, there needs to be a difference between the behavior of adults and child offenders, and if seen from the position of a child legally has not been burdened with obligations compared to adults, as long as a person is still called a child, as long as he is also not held accountable, if a problem arises against the child, efforts are made how their rights are protected by law. ${ }^{7}$ This is because there is a gap in the level of maturity between adults and children, both morally, cognitively, psychologically, and emotionally. ${ }^{8}$ Therefore, in building a juvenile justice system, the perspective should be that children who are in conflict with the law are basically victims, even though the child has committed a criminal act. ${ }^{9}$ Criminal law enforcement officers are discriminatory, unprofessional, side with the authorities or people who have assets of power and are not transparent. Such conditions give rise to service (disregard), distrust, disrespect and disobedience to the law and its correctional institutions. ${ }^{10}$

Based on the description above, the issues that are relevant to the juvenile justice system include at least the determination of the age of criminal responsibility for children according to the age and maturity level of the child. One of the important issues in the area of criminal justice policy is to provide a legal

\footnotetext{
3 Harkrisnowo, Harkristuti. (2002). Tantangan dan Agenda Hak-Hak Anak. Jakarta: Newsletter Komisi Hukum Nasional, Edisi Februari. p. 4.

4 Marlina. (2009). Peradilan Pidana Anak di Indonesia. Pengembangan Konsep Diversi dan Restorative Justice. Bandung: PT. Refika Aditama. p. 5.

5 Ujan, Andre Ata. (2009). Filsafat Hukum: Membangun Hukum, Membela Keadilan. Yogyakarta: Penerbit Kanisius. p. 45

6 Wahyono, Agung dan Siti Rahayu. (1983). Tinjauan Peradilan Anak di Indonesia. Jakarta: Sinar Grafika. p. 2.

${ }^{7}$ Kusumah, Mulyana W. (ed). (1986). Hukum dan Hak-hak Anak. Jakarta: CV. Rajawali. p. 3.

${ }^{8}$ Anwari, Hangama. Justice for The Children: The situation for children in conflict with the law in Afghanistan. UNICEF and AIHRC

9 Salam, Abdul dan Zen Zanibar, MZ. (1998). Reflek Keterpaduan Penyidikan, Penuntutan dan Peradilan dalam Penanganan Perkara. Jakarta: DISKUM POLRI. p. 12.

10 Harkrisnowo, Harkristuti. Menelaah Konsep Sistem Peradilan Pidana Terpadu (Dalam Konteks Indonesia) Seminar Keterpaduan Sistem Peradilan Pidana Anak. Danau Toba Medan tanggal 4-5 April 2002. p. 3.
} 
mechanism that reflects the transition from an innocent childhood to maturity and fully accountable under the criminal law. ${ }^{11}$

Seeing the conditions of handling cases of children in conflict with the law in Indonesia so far, there has been a new breakthrough to protect children from bad impacts in solving problems of children in conflict with the law, hereinafter referred to as children in conflict with the law through the juvenile criminal justice system as has been stated in Act No. 11 of 2012, which focuses on solving problems with restorative justice.

Based on the above background, the problem formulations in this research are: 1) How is the implementation of restorative justice in the Juvenile Criminal Justice System through diversion at the Semarang City District Attorney, 2) What are the obstacles in the implementation of restorative justice in the Juvenile Criminal Justice System through diversion at the Attorney General's Office Semarang City State.

After knowing the formulation of the problem, the objectives of this study are: 1) To study and analyze the implementation of restorative justice in the Juvenile Criminal Justice System through diversion at the Semarang City District Attorney. 2) To study and analyze obstacles in the implementation of restorative justice in the Juvenile Criminal Justice System through diversion at the Semarang City District Attorney.

\section{Research methods}

The approach method used in this research is the juridical empirical approach, which is research that examines or traces people's attitudes and attitudes towards the applicable law. An empirical juridical approach is used to provide a qualitative description of the implementation of restorative justice in the juvenile criminal justice system through diversion. ${ }^{12}$

The specifications used in this research are analytical descriptive research. The data used in this study use secondary data and primary data. Primary legal materials include: Supreme Court Regulation Number 4 of 2014 concerning the Implementation of Diversion in the Juvenile Criminal Justice System, and Attorney General Regulation No. 06/A/JA/04/2015 concerning Guidelines for Implementation of Diversion.

In this study, researchers used data collection techniques through field studies conducted by interviews and literature study by taking information from literature and documentation. Data obtained from both field studies and document studies on basicallyis level data that is analyzed qualitatively. Qualitative analysis, that is, after the data has been collected, it is then set forth in a logical description and systematic, then analyzed to obtain clarity in solving the problem, then conclusions are drawn inductively, namely from things that are general in nature to things that are specific.

${ }^{11}$ Graycar, Adam. (2000). The Age Of Criminal Responsibility. (Australian Institute Of Criminology. p. 112.

${ }^{12}$ Sunggono, Bambang. (1997). Metode Penelitian Hukum. Jakarta: Raja Grafindo Persada 


\section{Results and Discussion}

\subsection{Implementation of Restorative Justice in the Criminal Justice System through Diversion at the Semarang City District Attorney}

According to Article 1 Act No. 8 of 1981 concerning the Criminal Procedure Code (KUHAP), Judges are state judicial officials who are authorized by law to judge. Then the word "judge" is a series of actions by judges to accept, examine, and decide cases based on the principles of freedom, honesty and impartiality in the trial of a case and upholds 3 (three) principles of justice, namely simple, fast and low cost.

The function of the judge is to give a decision on a case filed, where in a criminal case, this is inseparable from a negative system of proof, which in principle determines that a right or event or mistake is deemed to have been proven, in addition to the existence of means of evidence according to law. Also determined the judge's conviction which is based on good moral integrity. ${ }^{13} \mathrm{~A}$ judge in imposing a sentence on a defendant may not impose the sentence unless with at least two valid evidence items, so that the judge is convinced that a criminal act has actually occurred and the defendant is guilty of committing it (Article 183 KUHAP). The legal evidence means: Witness statements, expert statements, guidance letters, defendants' statements or things which are generally known so that they do not need to be proven (Article 184 KUHAP). ${ }^{14}$

Judge in examining criminal cases, strives to find and prove material truth based on facts revealed in court and upholds the indictment formulated by the public prosecutor. A judge's decision is a decision pronounced by a judge because his position in a trial of a criminal case which is open to the public after carrying out the process and procedural law of criminal procedure generally contains the sentence of punishment or acquittal or waiver of all lawsuits is made in written form with the aim of solving the case there are 3 options possible decisions to be issued by the judge, namely: ${ }^{15}$ conviction or imposition of punishment (veroordeling), acquittal (vrijspraak), and verdict free from all lawsuits (onslag van alle rechtsvervolging).

Furthermore, in making decisions, there are several theories used by judges. According to Mackenzie, there are several theories or approaches that can be used by judges in considering a verdict in a case. In deciding a criminal case, a judge must decide in the fairest way and must comply with the applicable rules. According to Van Apeldoorn, judges must: Adjust laws with concrete factors, concrete events in society, and add laws if necessary. ${ }^{16}$

The main function of a judge is to give a decision on a case submitted to him, where in a criminal case this is inseparable from the negative evidence system

\footnotetext{
13 Rifai, Ahmad. (2010). Penemuan Hukum Oleh Hakim Dalam Perspektif Hukum Progresif. Jakarta: Sinar Grafika. p. 103

${ }_{14}$ Rahardjo, Satjipto. (1998). Bunga Rampai Permasalahan Dalam Sistem Peradilan Pidana. Jakarta: Pusat Pelayanan Keadilan dan Pengabdian Hukum. p. 11

${ }^{15}$ Hamzah, Andi. (2014). Hukum Acara Pidana Indonesia. Jakarta: Sinar Grafika. p. 284

16 Utrecht, E and Moch Saleh Djindang. (1983). Pengantar Dalam Hukum Indonesia. Jakarta: Sinar Harapan. p. 204
} 
(negative wetterlijke), which in principle determines that a right or event or error is deemed proven, in addition to the existence of tools. Evidence according to law is also determined by the judge's conviction which is based on good moral integrity. ${ }^{17}$

Protection of children is carried out in all aspects of life, including in this case in juvenile criminal justice, in child punishment emphasizes the rights of children, both as suspects, victims, defendants, and as prisoners. ${ }^{18}$ The purpose of holding juvenile justice is not only prioritizing the imposition of crimes, but also protection for the future of children from a psychological aspect by providing protection, guidance and education. ${ }^{19}$ The existence of Act No. 11 of 2012 concerning the Juvenile Criminal Justice System (hereinafter referred to as the Law on the Juvenile Criminal Justice System) contains several important changes, one of the solutions that can be taken in handling cases of juvenile crime is a restorative justice approach. Restorative justice is a settlement process carried out outside the criminal justice system by involving the victim, the perpetrator, the victim's family and perpetrator, the community and parties with an interest in a criminal act that occurs to reach an agreement and settlement. ${ }^{20}$

According to Act No. 11 of 2012 concerning the Juvenile Criminal Justice System, it places more emphasis on diversionary solutions. The process of implementing diversion holds the principle of restorative justice which pays close attention to the interests of the victim and the welfare of the child.

The substance stipulated in the SPPA Law includes the placement of children who undergo judicial processes to be placed in the Special Development Institution for Children (LPKA). The most basic substance in this law is strict regulation regarding Restorative Justice and Diversion which aims to avoid children from the judicial process so that they can avoid stigmatization of children who are in conflict with the law and it is hoped that children can return to the social environment naturally.

Regarding the regulation of Diversion, it is specifically regulated in Article 5 paragraph (3), which states that in the juvenile justice system it is obligatory to seek diversion. Furthermore, Article 8 paragraph (1) of the SPPA Law also stipulates that the diversion process is carried out through deliberation involving children and their parents/guardians, victims and/or their parents/guardians, community advisors, and professional social workers based on a restorative justice approach.

The diversion approach in restorative justice as regulated in Act No. 11 of 2012 concerning the Juvenile Criminal Justice System is a new breakthrough that is not recognized in the conventional Criminal Justice System. Restorative justice offers the best solution in solving criminal cases, namely by giving priority to the core problem of a crime. An important solution to pay attention to is to repair the

\footnotetext{
17 Rifai, Ahmad. (2010). Penemuan hukum. Jakarta: Sinar Grafika. p. 96

18 M Platt, Anthony. (1977). The Chid Savers; the Invention of Delinguency. Chicago and London: The University of Chicago Press, Scond Edition. p. 54.

${ }^{19}$ Gultom, Maidin. (2014). Perlindungan Hukum Terhadap Anak dalam Sistem Peradilan Pidana Anak Di Indonesia. Bandung: PT Refika Aditama. p. 93

20 Kusumaningrum, Santi. Penggunaan Diversi untuk Anak yang Berhadapan dengan hukum. http://www.idlo.int/bandaacehawareness.html.
} 
damage or loss caused by the crime. The improvement of the social order of the society which is disturbed by crime is an important part of the concept of restorative justice. ${ }^{21}$

\subsection{Obstacles in the Implementation of Restorative Justice in the Criminal Justice System through Diversion at the Semarang City District Attorney}

The government seeks to improve the legal protection system for children in conflict with the law in the Juvenile Criminal Justice System in Indonesia by issuing Act No. 11 of 2012 concerning the Juvenile Criminal Justice System which was later abbreviated as SPPA which was passed on 3 July 2012.

According to Article 1 paragraph (2) of Act No. 35 of 2014 concerning Child Protection, which is meant by child protection, is: all activities to guarantee and protect children and their rights in order to live grow and participate optimally in accordance with human dignity, and receive protection from violence and discrimination.

Naughty children need to be handled through a special judicial institution because children cannot possibly be treated the same as adults. Article 25 of Act No. 48 Year 2009 concerning Judicial Powers states that: "In the General Courts there can be specializations regulated by law".

Juvenile Criminal Court is one of the Special Courts that handles child criminal cases, in addition to several other Special Courts that apply in Indonesia, namely the Road Traffic Court and the Economic Court. Obstacles in the implementation of restorative justice in the Criminal Justice System through diversion are very likely to occur in solving children's cases with a restorative justice system.

Although it has been regulated in Act No. 11 of 2012 concerning the Juvenile Criminal Justice System, however, the application of restorative justice and diversion will face obstacles that can occur in its implementation. Referring to the factors that influence law enforcement put forward by Soerjono Soekanto, the obstacles to be faced in the application of restorative justice and diversion include: ${ }^{22}$ First, law or Act No. 11 of 2012 concerning the Criminal Justice System for Children. Article 15 states, the provisions regarding the guidelines for the implementation of the diversion process, procedures, and coordination of the implementation of diversion are regulated by a government regulation. Article 107 stipulates that the implementing regulations for this Law must be stipulated no later than 1 (one) year after this Law is enacted.

When this study was carried out there was no or no Government Regulation made of this Law, so that this would become an obstacle in the application of restorative justice and diversion in resolving crimes committed by children. Second, law enforcers, namely the parties who apply the law. As is generally the case in law enforcement, law enforcement officers who play a role in it are the

\footnotetext{
${ }^{21}$ Hadi, Supeno. (2010). Kriminalisasi Anak Tawaran Gagasan Radikal Peradilan Anak Tanpa Pemidanaan. Jakarta: PT Gramedia Pustaka Utama. p. 217

${ }^{22}$ Soekanto, Soerjono. (1983). Faktor-Faktor Yang Mempengaruhi Penegakan Hukum. Jakarta: PT. Raja Grafindo Persada. p. 5
} 
police, prosecutors and judges, if they still have retributive thoughts (punishment), it will become an obstacle in the application of restorative and diversionary justice. In addition, what is no less important is the parties involved in the application of restorative justice, if the parties do not reach an agreement, it will be difficult to apply restorative justice and diversion. Third, means or facilities that support law enforcement. That it cannot be denied that limited means or facilities will become an obstacle in the application of restorative justice and diversion. Facilities and infrastructure that can support the application of restorative justice and diversion are needed.

Children who are in conflict with the law must be placed in the Temporary Child Placement Institution (LPAS), but not all regions have LPAS. It is true that a large investment from the government is needed to establish LPAS, because children who are in conflict with the law have their rights inherent in them and this must be fulfilled by the government so that these children do not lose their rights even though they are currently facing legal problems. Fourth, the community environment. That it cannot be denied that limited means or facilities will become an obstacle in the application of restorative justice and diversion.

\section{Closing}

The implementation of Restorative Justice in the Criminal Justice System through Diversion at the Semarang City District Attorney has not been carried out. This is due to the need for time to adjust to the new regulations in effect, in order to meet the completeness of supporting infrastructure and equitable distribution of trained and reliable human resources in every judicial institution in various regions throughout Indonesia, especially those dealing with child crimes. The obstacle in the implementation of restorative justice in the Criminal Justice System through diversion at the Semarang City Public Prosecutor's Office is the lack of functioning of the child protection system in every case of children who are faced with the law. The application of restorative justice is appropriate for children who are dealing with the law, this can be seen in Act No. 11 of 2012 concerning the Child Criminal Justice System. One of the most important things in restorative justice in this law is diversion. Diversion is a process that has been recognized internationally as the best and most effective way of dealing with children in conflict with the law so as not to lose their rights as children.

The author suggests that in the case of child criminal cases, everyone should understand more about the importance of solving with a restorative justice model, both the community and law enforcement officials (police, prosecutors, judges) must lead the handling of child cases using restorative justice, because restorative justice is a criminal case settlement model that prioritizes repairing damage to the core of the problem for the recovery of a good condition for the victim, perpetrator, victim/perpetrator's family and the community involved.

\section{References}

\section{Journals}


[1] Kusumaningrum, Santi. Use of Diversion for Children Facing the Law. http://www.idlo.int/bandaacehawareness.html.

[2] Syahri, A. (2020). Law Enforcement against Policies Who Breached the Code of Conduct. Jurnal Daulat Hukum.Volume 3 Issue 3, ISSN: 2614560X.http://jurnal.unissula.ac.id/index.php/RH/article/view/11238.

[3] Yulianto, AB. (2020). Community Policing Strategy (Polmas) In The Implementation Of Bhabin kamtibmas Tasks As A Radical Detection Basis. Jurnal Daulat Hukum. Volume 3 Issue 3, ISSN: 2614-560X. http://jurnal.unissula.ac.id/index.php/RH/article/view/11245.

\section{Books}

Gunarsa, Singgih D (Peny). (2004). Dari Anak Sampai Lanjut Usia. Jakarta: PT BPK Gunung Mulia.

Reksodiputro, Mardjono. (1997). Hak Asasi Manusia dalam Sistem Peradilan Pidana. Jakarta: Pusat Pelayanan Keadilan dan Pengabdian Hukum Lembaga Kriminologi Universitas Indonesia.

Harkrisnowo, Harkristuti. (2002). Tantangan dan Agenda Hak-Hak Anak. Jakarta: Newsletter Komisi Hukum Nasional, Edisi Februari.

Marlina. (2009). Peradilan Pidana Anak di Indonesia. Pengembangan Konsep Diversi dan Restorative Justice. Bandung: PT. Refika Aditama.

Ujan, Andre Ata. (2009). Filsafat Hukum: Membangun Hukum, Membela Keadilan. Yogyakarta: Penerbit Kanisius.

Wahyono, Agung dan Siti Rahayu. (1983). Tinjauan Peradilan Anak di Indonesia. Jakarta: Sinar Grafika.

Kusumah, Mulyana W. (ed). (1986). Hukum dan Hak-hak Anak. Jakarta: CV. Rajawali.

Anwari, Hangama. Justice for The Children: The situation for children in conflict with the law in Afghanistan. UNICEF and AIHRC

Salam, Abdul dan Zen Zanibar, MZ. (1998). Reflek Keterpaduan Penyidikan, Penuntutan dan Peradilan dalam Penanganan Perkara. Jakarta: DISKUM POLRI.

Harkrisnowo, Harkristuti. Menelaah Konsep Sistem Peradilan Pidana Terpadu (Dalam Konteks Indonesia) Seminar Keterpaduan Sistem Peradilan Pidana Anak. Danau Toba Medan tanggal 4-5 April 2002.

Graycar, Adam. (2000). The Age Of Criminal Responsibility. (Australian Institute Of Criminology.

Sunggono, Bambang. (1997). Metode Penelitian Hukum. Jakarta: Raja Grafindo Persada

Rifai, Ahmad. (2010). Penemuan Hukum Oleh Hakim Dalam Perspektif Hukum Progresif. Jakarta: Sinar Grafika.

Rahardjo, Satjipto. (1998). Bunga Rampai Permasalahan Dalam Sistem Peradilan Pidana. Jakarta: Pusat Pelayanan Keadilan dan Pengabdian Hukum.

Hamzah, Andi. (2014). Hukum Acara Pidana Indonesia. Jakarta: Sinar Grafika.

Utrecht, E and Moch Saleh Djindang. (1983). Pengantar Dalam Hukum Indonesia. Jakarta: Sinar Harapan.

Rifai, Ahmad. (2010). Penemuan hukum. Jakarta: Sinar Grafika.

M Platt, Anthony. (1977). The Chid Savers; the Invention of Delinguency. Chicago and London: The University of Chicago Press, Scond Edition. 
Gultom, Maidin. (2014). Perlindungan Hukum Terhadap Anak dalam Sistem Peradilan Pidana Anak Di Indonesia. Bandung: PT Refika Aditama.

Kusumaningrum, Santi. Penggunaan Diversi untuk Anak yang Berhadapan dengan hukum. http://www.idlo.int/bandaacehawareness.html.

Hadi, Supeno. (2010). Kriminalisasi Anak Tawaran Gagasan Radikal Peradilan Anak Tanpa Pemidanaan. Jakarta: PT Gramedia Pustaka Utama.

Soekanto, Soerjono. (1983). Faktor-Faktor Yang Mempengaruhi Penegakan Hukum. Jakarta: PT. Raja Grafindo Persada.

\section{Regulations}

Criminal Procedure Code;

Criminal Code;

Attorney General's Regulation No. 06/A/J.A/04/2015 concerning Guidelines for Implementation of Diversion.

Supreme Court Regulation Number 4 of 2014 concerning Implementation of Diversion in the Juvenile Criminal Justice System;

Government Regulation Number 65 of 2015 concerning Guidelines for the Implementation of Diversion and Handling of Children Not Aged 12 (Twelve) Years Old;

The 1945 Constitution of the Republic of Indonesia;

Act No. 11 of 2012 concerning the Child Criminal Justice System, previously Act No. 3 of 1997 concerning Juvenile Court;

Act No. 17 of 2016 concerning Stipulation of Government Regulations in Lieu of Act No. 1 of 2016 concerning the Second Amendment to Act No. 23 of 2002 concerning Child Protection Into Law;

Act No. 35 of 2014 concerning Amendments to Act No. 23 of 2002 concerning Child Protection. 